\title{
Recommendations on how to provide cardiac rehabilitation services during the COVID-19 pandemic
}

\author{
H. M. C. Kemps · R. W. M. Brouwers - M. J. Cramer · H. T. Jorstad • E. P. de Kluiver · R. A. Kraaijenhagen • \\ P. M. J. C. Kuijpers - M. R. van der Linde - E. de Melker · S. F. Rodrigo - R. F. Spee - M. Sunamura - T. Vromen · \\ M. E. Wittekoek - Committee for Cardiovascular Prevention and Cardiac Rehabilitation of the Netherlands \\ Society of Cardiology
}

Published online: 16 July 2020

(C) The Author(s) 2020

\begin{abstract}
The ongoing coronavirus disease 2019 (COVID-19) crisis is having a large impact on acute and chronic cardiac care. Due to public health measures and the reorganisation of outpatient cardiac care, traditional centre-based cardiac rehabilitation is currently almost impossible. In addition, public health measures are having a potentially negative impact on lifestyle behaviour and general well-being. Therefore, the Working Group of Cardiovascular Prevention and Rehabilitation of the Dutch Society of Cardiology has formulated practical recommendations for the provision of cardiac rehabilitation during the COVID-19 pandemic, by using telerehabilitation programmes without face-to-face contact based on current guidelines supplemented with new insights and experiences.
\end{abstract}

H. M. C. Kemps $(\bowtie) \cdot$ R. W. M. Brouwers · R. F. Spee Department of Cardiology, Máxima Medical Centre, Veldhoven, The Netherlands

h.kemps@mmc.nl

H. M. C. Kemps

Department of Industrial Design, Eindhoven University of Technology, Eindhoven, The Netherlands

\section{J. Cramer}

Department of Cardiology, University Medical Centre, Utrecht, The Netherlands

\section{H. T. Jorstad}

Department of Cardiology, Amsterdam University Medical

Centre, University of Amsterdam, Amsterdam, The

Netherlands

\section{E. P. de Kluiver}

Isala Heart Centre, Zwolle, The Netherlands

\section{R. A. Kraaijenhagen}

CardioVitaal Cardiac Rehabilitation, Amsterdam, The Netherlands
Keywords Cardiac rehabilitation - Cardiac telerehabilitation · Telemonitoring · Coronary artery disease

\section{Introduction}

During the coronavirus disease 2019 (COVID-19) pandemic many elective and outpatient healthcare activities have been cancelled or postponed. Also, a decline in admissions due to cardiac disease has been observed [1]. In many Dutch hospitals and specialised rehabilitation clinics, cardiac rehabilitation (CR) programmes have been shut down partially or even completely. In particular, group-based exercise training interventions and exercise testing are hardly possible. In addition, the public health measures

\section{P. M. J. C. Kuijpers · T. Vromen}

Department of Cardiology, Maastricht University Medical Centre, Maastricht, The Netherlands

\section{R. van der Linde}

Department of Cardiology, Nij Smellinghe Hospital, Drachten, The Netherlands

\section{E. de Melker}

Department of Cardiology, OLVG, Amsterdam, The

Netherlands

\section{S. F. Rodrigo}

Basalt Rehabilitation, Leiden, The Netherlands

M. Sunamura

Capri Cardiac Rehabilitation, Rotterdam, The Netherlands

M. E. Wittekoek

HeartLife Klinieken, Utrecht, The Netherlands 
implemented during the COVID-19 pandemic, above all quarantine and isolation, have been shown to be associated with anxiety, anger and stress, which is associated with unhealthy lifestyle behaviour, including a reduction in physical activity and an unhealthy diet [2]. Therefore, there is an urgent need for upscaling and reorganisation of CR and secondary prevention services. Recently, the Working Group of Cardiovascular Prevention and Rehabilitation of the Dutch Society of Cardiology has formulated practical recommendations for CR during the COVID-19 pandemic. These recommendations are partly based on a recent statement from the Secondary Prevention and Rehabilitation Section of the European Association of Preventive Cardiology [3], supplemented with insights from the recently published Dutch Telerehabilitation guidelines [4] and practical experiences from the largest Dutch CR centres. The importance of continuing the delivery of (cardiac) rehabilitation during the COVID19 pandemic by means of telerehabilitation programmes without face-to-face contact is emphasised by the prompt reimbursement of these programmes by the Netherlands Health Institute (NZa) and with support from the Netherlands Health Institute (ZiN).

\section{General recommendations}

- Support acute cardiac wards in providing summarised but highlighted important information/ recommendations on secondary prevention (not forgetting physical activity and mental impact) before hospital discharge.

- In the case of shortened CR programmes, concentrate efforts on the main core components (i.e. lifestyle risk management, psychosocial support, medical advice, education) with an individualised approach based on psychological symptoms, residual cardiac risk and lifestyle assessment.

- Replace face-to-face sessions by remote assessment and monitoring/guiding, according to local equipment and expertise (telephone, text messaging, e-mails, video consultations, web-based platforms and applications).

- Perform patient assessment and risk stratification with an exercise test whenever possible. If not possible, use other tools to assess the cardiovascular risk and physical fitness in order to provide personalised exercise advice and to guide telerehabilitation (see Tab. 1).

- For COVID-19-positive patients, postpone the exercise programme if fever, symptoms or other signs of COVID-19 infection are present [3]. Evaluate exercise resumption on an individual basis. In general, in patients with light-to-moderate symptoms, gradually restart the exercise programme after a feverfree period of 1 week and a symptom-free period of $48 \mathrm{~h}$. Whenever possible, do not postpone all other CR components but provide them remotely (see Tab. 1).

- For general safety and hygiene measures take into account the recommendations of the Dutch National Institute for Public Health and the Environment (Rijksinstituut voor Volksgezondheid en Milieu,RIVM) and the Dutch Federation of Medical Specialists (Federatie Medisch Specialisten, FMS) [5, $6]$.

Specific recommendations are presented in Tab. 1 .

Conflict of interest H.M.C. Kemps, R.W.M. Brouwers, M.J. Cramer,H.T. Jorstad, E.P. de Kluiver, R.A. Kraaijenhagen, P.M.J.C. Kuijpers, M.R. van der Linde, E. de Melker, S.F. Rodrigo, R.F. Spee, M. Sunamura, T. Vromen and M.E. Wittekoek declare that they have no competing interests.

Open Access This article is licensed under a Creative Commons Attribution 4.0 International License, which permits use, sharing, adaptation, distribution and reproduction in any medium or format, as long as you give appropriate credit to the original author(s) and the source, provide a link to the Creative Commons licence, and indicate if changes were made. The images or other third party material in this article are included in the article's Creative Commons licence, unless indicated otherwise in a credit line to the material. If material

Table 1 Modes of delivery of cardiac rehabilitation $(C R)$ according to current guidelines and recommendations for alternatives during the coronavirus disease 2019 (COVID-19) pandemic

\begin{tabular}{|c|c|c|}
\hline & $\begin{array}{l}\text { Current guideline } \\
\text { [7] }\end{array}$ & Recommendations during COVID-19 pandemic \\
\hline Assessment & $\begin{array}{l}\text { Assessment of five } \\
\text { domains according } \\
\text { to the Dutch clini- } \\
\text { cal algorithms for } \\
\text { cardiac rehabilita- } \\
\text { tion (Poliklinische } \\
\text { Indicatiestelling } \\
\text { Hartrevalidatie) } \\
2012 \text { [8]: physical } \\
\text { functioning, psycho- } \\
\text { logical functioning, } \\
\text { social functioning, } \\
\text { cardiovascular } \\
\text { risk profile, risk } \\
\text { behaviour }\end{array}$ & $\begin{array}{l}\text { Assessment of five domains according to the Dutch clinical algorithms for cardiac rehabilitation (Poliklinische Indicati- } \\
\text { estelling Hartrevalidatie) } 2012[8] \text { : } \\
\text { If exercise testing is not possible use alternative validated tools to assess physical fitness for risk asessment (see 'Exer- } \\
\text { cise programme'), e.g.: } \\
\text { - HUNT non-exercise prediction model [9] } \\
\text { - The 2-min step test [10] or other validated submaximal exercise tests may be considered if performed under direct } \\
\text { video-supervision }\end{array}$ \\
\hline
\end{tabular}


Table 1 (Continued)

\begin{tabular}{|c|c|c|}
\hline & $\begin{array}{l}\text { Current guideline } \\
\text { [7] }\end{array}$ & Recommendations during COVID-19 pandemic \\
\hline $\begin{array}{l}\text { Exercise } \\
\text { programme }\end{array}$ & $\begin{array}{l}\text { Group sessions at } \\
\text { CR centre } \\
\text { Telerehabilitation } \\
\text { according to the } \\
\text { Dutch Society of } \\
\text { Cardiology (NVVC) } \\
\text { guideline adden- } \\
\text { dum concerning } \\
\text { telerehabilitation } \\
\text { [4]: training pre- } \\
\text { scription and risk } \\
\text { assessment based } \\
\text { on ergometry and } \\
\text { monitoring with } \\
\text { heart rate sensor } \\
\text { and activity tracker }\end{array}$ & 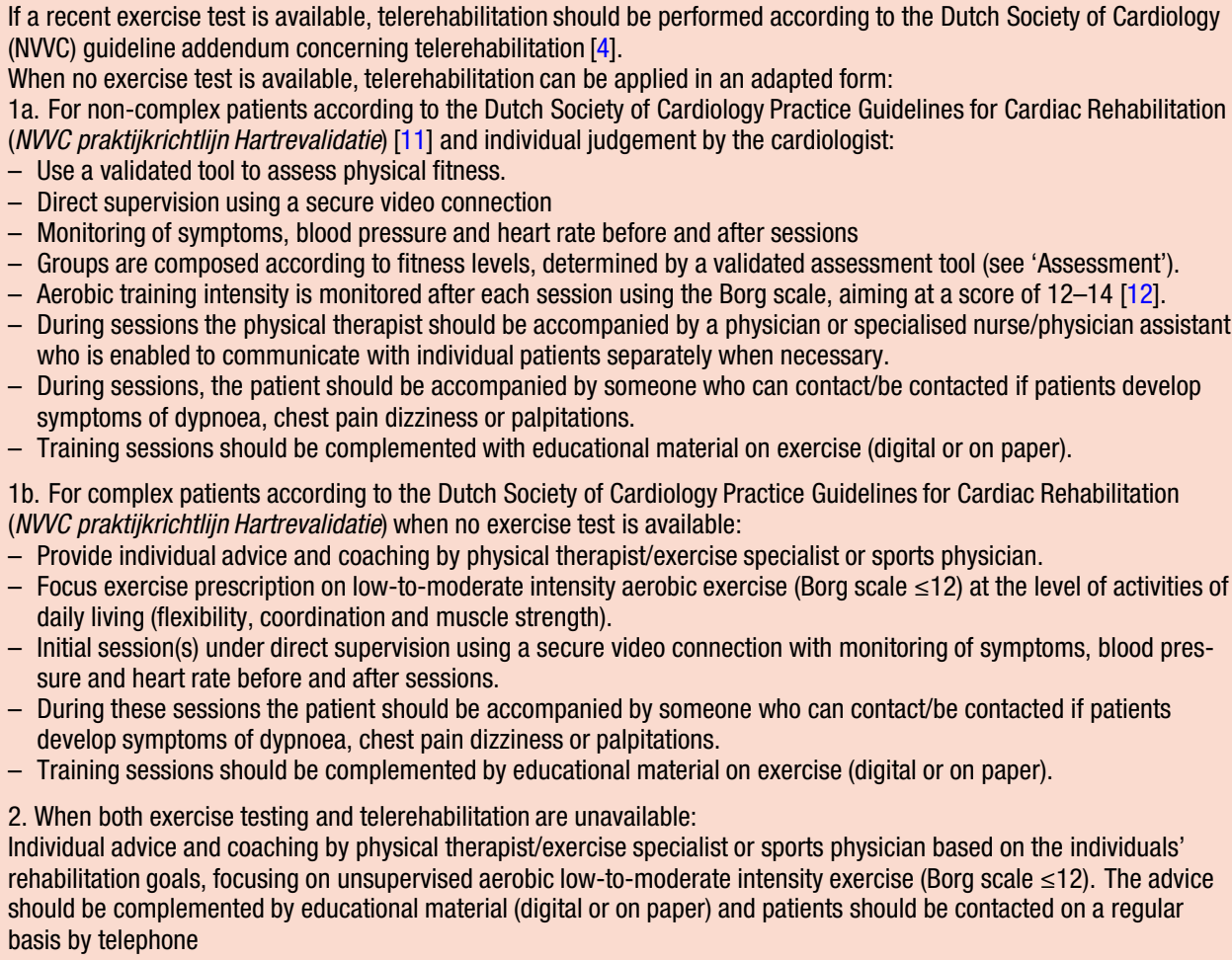 \\
\hline $\begin{array}{l}\text { Psychoedu- } \\
\text { cational pre- } \\
\text { vention (PEP) } \\
\text { programme }\end{array}$ & $\begin{array}{l}\text { Group sessions at } \\
\text { CR centre } \\
\text { Remote PEP pro- } \\
\text { gramme according } \\
\text { to NVVC guideline: } \\
\text { individual intake } \\
\text { and remote guid- } \\
\text { ance using an } \\
\text { online platform }\end{array}$ & $\begin{array}{l}\text { Individual intake and group sessions using a secure group video connection } \\
\text { Remote PEP programme according to NVVC guideline: individual intake and remote guidance using an online platform }\end{array}$ \\
\hline $\begin{array}{l}\text { Education } \\
\text { programme }\end{array}$ & $\begin{array}{l}\text { Group sessions at } \\
\text { CR centre }\end{array}$ & $\begin{array}{l}\text { Individual or group remote educational consultation(s) } \\
\text { Online material and/or interactive e-learning }\end{array}$ \\
\hline $\begin{array}{l}\text { Relaxation } \\
\text { programme }\end{array}$ & $\begin{array}{l}\text { Group sessions at } \\
\text { CR centre }\end{array}$ & Group or individual sessions using a secure video connection \\
\hline $\begin{array}{l}\text { Individual } \\
\text { treatment } \\
\text { dietician/ } \\
\text { psychologist/ } \\
\text { social } \\
\text { worker }\end{array}$ & $\begin{array}{l}\text { Outpatient consulta- } \\
\text { tions }\end{array}$ & Remote consultations using a secure video connection or telephone \\
\hline $\begin{array}{l}\text { Individual } \\
\text { medical } \\
\text { treatment }\end{array}$ & $\begin{array}{l}\text { Outpatient consulta- } \\
\text { tions } \\
\text { Lab testing and } \\
\text { physical exam, } \\
\text { blood pressure }\end{array}$ & $\begin{array}{l}\text { Remote consultations using a secure video connection or telephone } \\
\text { Lab testing, blood pressure and heart rate measurement at home using validated sensors and educational material }\end{array}$ \\
\hline
\end{tabular}

is not included in the article's Creative Commons licence and your intended use is not permitted by statutory regulation or exceeds the permitted use, you will need to obtain permission directly from the copyright holder. To view a copy of this licence, visit http://creativecommons.org/licenses/by/4.0/.

\section{References}

1. De Rosa S, Spaccarotella C, Basso C, et al. Reduction of hospitalizations for myocardial infarction in Italy in the COVID-19 era. Eur Heart J. 2020;41(22):2083-8.

2. Mattioli AV, Ballerini Puviani M, Nasi M, et al. COVID-19 pandemic: the effects of quarantine on cardiovascular risk. Eur J Clin Nutr. 2020;74:852-5. 
3. https://www.escardio.org/Education/Practice-Tools/ CVD-prevention-toolbox/recommendations-on-how-toprovide-cardiac-rehabilitation-activities-during-the-c.

4. Committee for Cardiovascular Prevention and Cardiac Rehabilitation of the Netherlands Society of Cardiology, Landelijk Multidisciplinair Overleg Hartrevalidatie. Addendum telerevalidatiein multidisciplinairerichtlijn hartrevalidatie. 2018. https://www.nvvc.nl/Kwaliteit/Richtlijnen/ Addendum\%20richtlijn\%20hartrevalidatie\%20-1-.pdf.

5. https://www.rivm.nl/coronavirus- covid-19/ professionals/buiten-ziekenhuis/veelgestelde-vragen.

6. https://www.demedischspecialist.nl/nieuws/leidraadpersoonlijke-bescherming-de-poliklinische-setting.

7. Netherlands Society of Cardiology/Netherlands Heart Foundation. Multidisciplinary guidelines for cardiac rehabilitation. 2011. https://www.nvvc.nl/Richtlijnen/ Multidisciplinaire\%20Richtlijn\%20Hartrevalidatie\%2020 $11 \% 2023052011$.pdf.

8. Committee for Cardiovascular Prevention and Cardiac Rehabilitation of the Netherlands Society of Cardiology, Landelijk Multidisciplinair Overleg Hartrevalidatie. Beslisboom Poliklinische Indicatiestelling Hartrevalidatie
2012. 2012. https://www.nvvc.nl/Richtlijnen/Beslisboom \%20Hartrevalidatie\%202012\%20-website.pdf.

9. Nes BM, et al. Estimating VO2peak from a nonexercise prediction model: the HUNT Study, Norway. Med SciSports Exerc. 2011;43(11):2024-30.

10. Bohannon RW, Crouch RH. Two-minute step test of exercise capacity: systematic review of procedures, performance, and clinimetric properties. J Geriatr Phys Ther. 2019;42(2):105-12.

11. Committee for Cardiovascular Prevention and Cardiac Rehabilitation of the Netherlands Society of Cardiology, Landelijk Multidisciplinair Overleg Hartrevalidatie. NVVC Practice guidelines for cardiac rehabilitation. 2011. https://www.nvvc.nl/Richtlijnen/Geautoriseerde \%20NVVC\%20Praktijkrichtlijn\%20Hartrevalidatie\%20 maart\%202011.pdf.

12. Ambrosetti M, Abreu A, Corrà U, et al. Secondary prevention through comprehensive cardiovascular rehabilitation: from knowledge to implementation. 2020 update. A position paper from the Secondary Prevention and Rehabilitation Section of the European Association of Preventive Cardiology. Eur J Prev Cardiol. 2020; https://doi.org/10. $1177 / 2047487320913379$. 